\title{
Covid-19 dan Kinerja Saham Perusahaan Indonesia: Pendekatan Event-Study
}

\author{
Wulan Budi Astuti* dan Atieq Amjadallah Alfie \\ Jurusan akuntansi, Fakultas Ekonomi, Universitas Wahid Hasyim \\ "Email: wulanbudiastuti445@gmail.com
}

\begin{abstract}
Abstrak
Hampir seluruh sektor terkena dampak Corona Virus Disease 19 (COVID-19) termasuk sektor Pasar modal. Indeks Harga Saham Gabungan (IHSG) selama pandemi mengalami penurunan hingga titik terendah di awal bulan April. Penelitian ini bertujuan untuk menguji pengaruh COVID-19 terhadap pergerakan harga saham perusahaan di Indonesia dengan menggunakan pendekatan event study. Hampir seluruh industri mengalami penurunan pendapatan dan harga saham yang signifikan selama periode COVID-19. Nilai cummulative abnormal return rata-rata dari industri tersebut bernilai negatif dan signifikan, menunjukkan pengaruh signifikan dari COVID-19. Temuan empiris penelitian ini dapat digunakan sebagai referensi pelaku bisnis untuk mempersiapkan bisnis dalam menghadapi pandemi serupa.
\end{abstract}

Kata kunci: Covid-19, Abvnormal return, Event study

\section{PENDAHULUAN}

Diawal tahun 2020, Dunia digemparkan dengan merebaknya wabah mematikan yang disebut dengan nama Corona Virus Desease (COVID-19). WHO mengumumkan COVID-19 sebagai pandemi global pada 11 Maret 2020. COVID-19 pertama kali mewabah di Kota Wuhan, Tiongkok di akhir tahun 2019. Seiring berjalannya waktu, kasus COVID-19 terus meningkat. Awal Maret tercatat mencapai 1 juta orang yang telah terinfeksi di seluruh Dunia. Hingga saat ini ada sebanyak 216 negara yang terjangkit virus ini, termasuk Indonesia (Data WHO, Agustus 2020).

Kasus COVID-19 pertama kali resmi diumumkan terjadi di Indonesia pada tanggal 3 Maret 2020 oleh Bapak Joko Widodo Presiden Indonesia. Pasien pertama yang positif terinfeksi adalah 2 warga Depok, Jawa Barat. Sebelumnya satu diantara kedua pasien tersebut berinteraksi dengan warga Negara jepang yang telah terbukti positif COVID-19. Pada tanggal 9 April 2020, COVID-19 telah menyebar ke 34 Provinsi. DKI Jakarta, Jawa Timur dan Jawa Tengah menjadi provinsi dengan jumlah kasus terbanyak. Guna mengantisipasi terus melonjaknya kasus COVID1-19 di Indonesia maka pada tanggal 31 maret 2020, pemerintah Indonesia memutuskan untuk menerapkan kebijakan pembatasan sosial berskala besar (PSBB). Tempat-tempat umum seperti area perbelanjaan, area wisata, perkantoran dan bahkan sekolah-sekolah ditutup untuk sementara waktu guna mengurangi intensitas berkumpulnya warga. Hingga awal bulan Agustus jumlah total kasus COVID-19 adalah sebanyak 125.396 kasus. Indonesia menempati urutan ke-2 kasus positif terbanyak di Asia Tenggara setelah Filipina.

Kehadiran COVD-19 memberikan dampak yang luar biasa hampir di setiap sendi kehidupan masyarakat. Tidak hanya dari segi kesehatan, sosial dan ekonomi ikut merasakan efek persebaran COVID-19. Lahmiri \& Bekiros (2020) menyebutkan bahwa COVID-19 memberikan dampak pada perekonomian seperti menurunnya tingkat penjualan, perubahan perilaku konsumen, Penurunan tingkat produksi, keterbatasan keuangan perusahaan, dan peningkatan jumlah pengangguran. Hal ini seakan didukung oleh pernyataan dari Kementerian Keuangan RI. Kementerian keuangan RI mengatakan setidaknya terdapat beberapa dampak utama COVID-19 bagi perekonomian Indonesia mulai dari masalah ketenagakerjaan hingga perindustrian di Tanah Air.

Sektor pasar modal turut terkena dampak persebaran COVID-19. Umumnya, Pasar modal akan merespon jika terjadi peristiwa yang besar (Al-Awadhi et al., 2020) seperti COVID-19. COVID-19 telah menciptakan risiko yang belum pernah terjadi sebelumnya, menyebabkan investor mengalami kerugian yang signifikan dalam waktu yang singkat (Zhang et al., 2020). COVID-19 memberikan dampak yang luar biasa pada pasar modal di seluruh dunia. Pasar modal AS mengalami penurunan hampir 30\% dalam kuartal pertama tahun 2020 (Haroon \& Rizvi, 2020). Begitu pula Pasar modal Indonesia. Sejak diumumkannya kasus COVID-19 pertama yang terjadi di Indonesia pada Maret lalu, Indeks Harga Saham Gabungan (IHSG) terus mengalami penurunan. 
IHSG yang tadinya di atas 6.300 terus turun hingga mencapai level terendahnya di angka 3.937 di akhir bulan April. Penurunan secara terus menerus ini menimbulkan kekhawatiran sehingga berbagai kebijakan diturunkan untuk mendorong peningkatan kembali harga saham yang terus menerus turun.

Banyak peneliti yang telah memfokuskan penelitiannya pada COVID-19 dan beberapa peneliti meneliti dampak dari COVID-19 (Lahmiri \& Bekiros, 2020; Al-Awadhi et al., 2020; Tahir \& Batool, 2020; He et al., 2020). Penelitian yang memfokuskan diri pada reaksi pasar modal masih terbilang sedikit. Penting untuk mengkaji pengaruh dari COVID-19 tidak hanya dari dampaknya terhadap perusahaan Indonesia tetapi juga dari segi reaksi pasar modalnya. Penelitian ini menguji ada tidaknya pengaruh COVID-19 terhadap pergerakan harga saham perusahaan publik di Indonesia. Penelitian ini akan menjelaskan dampak penyakit mematikan ini pada harga saham perusahaan publik Indonesia dan dapat digunakan sebagai referensi mempersiapkan bisnis menghadapi pandemi serupa.

\section{Efficient Market Hypothesis}

Suatu pasar dikatakan efisien ketika harga sekuritas terus menerus menyesuaikan diri terhadap informasi baru yang masuk ke Pasar, dengan demikian harga sekuritas pada saat itu dapat mencerminkan semua informasi yang tersedia. Terdapat 3 asumsi dasar dari pasar efisien. Pertama, terdapat partisipan dalam jumlah yang besar dengan tujuan memaksimalkan profit melakukan analisis dan penilaian terhadap sekuritas. Kedua, informasi baru masuk ke pasar secara acak dan tidak saling bergantung. Terakhir, keputusan investor untuk membeli atau menjual sekuritas menyebabkan harga saham terus menerus disesuaikan untuk menunjukan pengaruh dari informasi baru yang masuk ke pasar (Reilly \& Brown, 2019).

Efficient market hypothesis (EMH) pertama kali dikemukakan oleh fama (1970). Menurutnya dalam pasar yang efisien investor memiliki keyakinan bahwa harga sekuritas sepenuhnya mencerminkan semua informasi yang tersedia dalam pasar sehingga return yang diharapkan konsisten dengan risikonya. Lebih lanjut fama (1970) membagi EMH menjadi 3 subhipotesis. Pertama pasar bentuk lemah (weak form), mengasumsikan bahwa harga saham saat ini mencerminkan seluruh informasi pasar historis yang beredar. Kedua pasar setengah kuat (Semi strong form), mengasumsikan bahwa harga sekuritas terus disesuaikan dengan semua informasi publik (informasi market dan non-market) yang masuk ke pasar, sehingga harga sekuritas saat ini mencerminkan semua informasi publik secara penuh. Ketiga Pasar bentuk kuat (Strong form), mengasumsikan bahwa harga sekuritas secara penuh mencerminkan semua informasi yang tersedia baik informasi publik maupun informasi privat, sehingga tidak ada investor tertentu yang memiliki akses monopoli pada informasi yang membentuk harga.

\section{Event Study Methode}

Event Study Methode banyak digunakan untuk menguji pengaruh suatu peristiwa ekonomi terhadap nilai suatu perusahaan (Chen et al., 2007). Umumnya metode ini diterapkan di bidang pasar modal, guna menguji pengaruh terjadinya suatu peristiwa terhadap pasar modal suatu negara. Pengaruh terjadinya suatu peristiwa terhadap pasar modal dapat dilihat dari seberapa cepat harga sekuritas menyesuaikan diri terhadap peristiwa tersebut (Reilly \& Brown, 2019). Studi ini sering diterapkan untuk menguji pasar bentuk setengah kuat (semi strong form).

Ada beberapa tahapan yang harus dilakukan dalam menerapkan ESM ini (Setyawasih, 2007), yaitu: pertama, definisikan event yang diminati berupa informasi baru yang tersedia di pasar. Kedua, menyusun teori pendukung untuk menjelaskan reaksi pasar terhadap peristiwa tersebut. Ketiga, mengidentifikasi perusahaan atau sektor yang terkena dampak dan identifikasi waktu terjadinya peristiwa (event dates). Keempat, menentukan sebuah event window yang tepat dan sesuaikan jaraknya. Kelima, mengeliminasi atau menyesuaikan perusahaan yang mengalami kejadian lain yang relevan selama event window. Keenam, menghitung abnormal return selama event window dan menguji signifikansinya. Ketujuh, mendesain kerangka pengujian abnormal return, mendefinisikan null hypothesis dan menentukan teknik untuk menyatukan abnormal return dari perusahaan secara individu. Kedelapan, gunakan boostrap jika sampel yang digunakan berukuran kecil. Kesembilan, menggambarkan teori yang menjelaskan variasi crossectional dalam abnormal return dan mengujinya secara ekonometrik. Terakhir, menginterpretasikan hasilnya. 
Suatu event study dikatakan valid jika memenuhi tiga asumsi berikut:

1. Merupakan pasar efisien (Market Efficient)

Suatu pasar dikatakan efisien ketika harga sekuritas terus menerus menyesuaikan diri terhadap informasi baru yang masuk ke Pasar, dengan demikian harga sekuritas pada saat itu dapat mencerminkan semua informasi yang tersedia.

2. Event tidak dapat diantisipasi (Unanticipated event).

Suatu event diumumkan melalui pers, dan pasar tidak memiliki informasi tersebut sebelumnya. Pelaku pasar murni mendapatkan informasi dari pengumuman pers. Abnormal return merupakan hasil dari reaksi pasar terhadap kehadiran informasi baru yang tidak diantisipasi sebelumnya.

3. Tidak ada pengaruh lain yang berbaur selama event window (confounding effect).

Event window harus terbebas dari pengumuman event lainnya. Penentuan event window yang terlalu panjang atau lama dikhawatirkan dapat terpengaruh oleh lebih banyak event, sehingga hasilnya menjadi bias.

\section{Cumulative Abnormal Return dan Hipothesis}

Abnormal return sering digunakan untuk mengukur kinerja surat berharga dan juga sebagai dasar penentuan efisiensi pasar. Abnormal return umumnya terjadi di sekitar waktu suatu event diumumkan sebagai akibat peningkatan signifikan aktivitas perdagangan dalam pasar. Abnormal return merupakan selisih antara actual return dan expected return pada setiap surat berharga, seperti yang terlihat dalam formula berikut:

$$
A R_{i t}=R_{i t}-E\left[R_{i t}\right]
$$

Dimana $A R_{i t}=$ abnormal return saham i selama periode $\mathrm{t} ; R_{i t}=$ tingkat pengembalian aktual dari saham i selama periode $\mathrm{t}$; dan $E\left[R_{i t}\right]=$ tingkat pengembalian yang diharapkan dari saham i selama periode $\mathrm{t}$.

Tingkat actual return dari suatu saham dapat dihitung dengan menggunakan rumus berikut:

$$
R_{i t}=\frac{P_{i t}-P_{i t-1}}{P_{i t-1}}
$$

Dimana $P_{i t}=$ harga saham i selama periode t; dan $P_{i t-1}=$ harga saham i selama periode $\mathrm{t}-1$ (hari sebelumnya).

Sedangkan untuk menentukan tingkat pengembalian yang diharapkan dapat menggunakan salah satu dari tiga metode berikut: 1) Mean adjusted model menganggap pengembalian yang diharapkan memiliki nilai yang konstan yang sama dengan rata-rata pengembalian aktual sebelumnya selama periode estimasi; 2) Market model menentukan pengembalian yang diharapkan melalui dua langkah. Pertama membentuk model ekspektasi dengan menggunakan data realisasi selama periode estimasi (actual return). Kedua mengestimasi pengembalian yang diharapkan pada periode jendela dari model ekspektasi tersebut dengan menggunakan regresi ordinary least square (OLS) ; dan 3) Market adjusted model menganggap penduga terbaik untuk mengestimasi pengembalian suatu saham adalah pengembalian inddeks pasar saat tersebut. Penelitian ini menggunakan market adjusted model untuk menghitung tingkat pengembalian saham yang diharapkan. Dengan demikian pengembalian yang diharapkan akan dihitung dengan menggunakan rumus berikut:

$$
R_{m t}=\frac{I H S G_{t}-I H S G_{\mathrm{t}-1}}{I H S G_{\mathrm{t}-1}}
$$

Dimana $I H S G_{t}=$ IHSG selama periode t; dan $I H S G_{t-1}=$ IHSG selama periode t-1 
Cumulative abnormal return merupakan jumlah abnormal return hari pertama hingga hari terakhir. Perhitungan CAR dapat dilakukan dengan persamaan berikut:

$$
C A R_{i, t}=\sum_{a=t 5}^{t} A R
$$

Dimana $C A R_{i, t}=$ Cumulative abnormal return saham i; $A R=$ Abnormal return saham i pada hari ke a, yaitu mulai dari awal periode hingga ke t.

Jika COVID-19 menyebabkan abnormal return, t-statistik harus berbeda secara signifikan dari Nol. Adapun hipotesis penelitian ini adalah :

H1 : Terdapat perbedaan antara Cumulative abnormal return sebelum dan setelah COVID-

19 pada perusahaan publik Indonesia.

\section{METODE PENELITIAN}

Objek penelitian yang digunakan dalam penelitian ini adalah perusahaan publik yang terdaftar di BEI selama periode pengamatan. Periode pengamatan penelitian ini adalah 9 hari disekitar tanggal pengumuman kasus COVID pertama di Indonesia, yaitu 4 hari sebelum (T-4), hari pengumuman (T0) dan 4 hari setelah pengumuman $(\mathrm{T}+4)$. Hari pengumuman adalah tanggal 3 Maret 2020. Selama periode pengamatan terd apat 683 perusahaan yang tersebar ke-9 Sektor yaitu sektor pertanian, sektor pertambangan, sektor industri dasar dan kimia, sektor aneka industri, sektor industri barang konsusmsi, sektor properti, realestate dan konstruksi bangunan, sektor utilitas, infrastruktur dan transportasi, sektor keuangan serta sektor perdagangan, jasa dan investasi.

Data yang digunakan adalah data kuantitatif yang bersumber dari data sekunder berupa clossing price harian dan Indeks Harga Saham Gabungan (IHSG) harian. Data tersebut diperoleh dari situs resmi BEI yaitu idx.co.id.

Penelitian ini menggunakan event study methode (ESM) untuk menganalisis dampak dari COVID-19 pada kinerja perusahaan publik Indonesia. Metode ini secara khusus melihat pengaruh pengumuman suatu event, dalam penelitian ini adalah event pertama kali kasus COVID-19 diumumkan di Indonesia, terhadap return perusahaan. Pertama penelitian ini memperkirakan return saham saat COVID-19 belum terjadi. Return saham yang terjadi sebagai akibat adanya event yang diumumkan seperti COVID-19 disebut dengan Abnormal return. Abnormal return (AR) merupakan selisih antara actual return dan expected return disekitar event date. AR bernilai positif jika event yang diumumkan merupakan berita yang baik. Hal ini menunjukan bahwa pasar percaya pengumuman event tersebut akan meningkatkan nilai perusahaan. Sebaliknya, AR bernilai negatif jika event yang diumumkan merupakan berita yang buruk. Hal ini menunjukan bahwa pasar percaya pengumuman event tersebut akan menurunkan nilai perusahaan (Chen et al., 2007).

Kemudian penelitian ini menghitung Cumulative abnormal return (CAR) di sekitar event date, untuk melihat dampak pengumuman tersebut. Setelah itu pengujian signifikansi statistik CAR akan dilakukan. Jika CAR berbeda dari nol, maka dapat dikatakan bahwa event tersebut secara signifikan berpengaruh terhadap harga saham.

\section{HASIL DAN PEMBAHASAN}

Tabel 1 menunjukan statistik deskriptif dari data penelitian ini. Dapat dilihat bahwa jumlah sampel penelitian ini adalah sebanyak 2.732. Nilai rata-rata Cumulative abnormal return (CAR) sebelum pengumuman kasus COVID-19 di Indonesia adalah 0,017 dengan CAR minimum sebesar -0,43 dan CAR maksimum sebesar 0,58. Sedangkan Nilai rata-rata Cumulative abnormal return (CAR) setelah pengumuman kasus COVID-19 di Indonesia adalah 0,019 dengan CAR minimum sebesar -0,42 dan CAR maksimum sebesar 0,93. Hal ini menunjukan terjadi peningkatan rata-rata nilai CAR setelah terjadinya pengumuman kasus COVID-19.

Tabel 1. Descriptive Statistic

\begin{tabular}{llrrrr}
\hline & N & \multicolumn{1}{c}{ Mean } & Std. Deviation & \multicolumn{1}{c}{ Minimum } & \multicolumn{1}{c}{ Maximum } \\
\hline CAR (T-) & 2732 & 0,017 & 0,077 & $-0,428$ & 0,576 \\
CAR (T+) & 2732 & 0,019 & 0,081 & $-0,418$ & 0,930 \\
\hline
\end{tabular}

Sumber: Data yang diolah (2020) 
Sebelum melakukan uji beda, perlu dilakukan uji normalitas terlebih dahulu. Jika data penelitian terdistribusi normal, maka uji beda dilakukan dengan menggunakan paired T-test. Sebaliknya, juka data penelitian ini tidak terdistribusi secara normal maka uji beda akan dilakukan dengan menggunakan Wilcoxon signed rank test. Tabel 2 menunjukan hasil uji normalitas dengan Shapiro-Wilk test.

Tabel 2. Uji Normalitas

\begin{tabular}{ccccccc}
\hline & \multicolumn{3}{c}{ Kolmogorov-Smirnov ${ }^{\mathrm{a}}$} & \multicolumn{3}{c}{ Shapiro-Wilk } \\
\hline & Statistic & $\mathrm{df}$ & Sig. & Statistic & $\mathrm{df}$ & Sig. \\
DIFF_CAR & 0,163 & 2732 & 0,000 & 0,825 & 2732 & 0,000 \\
\hline
\end{tabular}

Sumber: Data yang diolah (2020)

Tabel tersebut menunjukan nilai signifikansi sebesar $0,000(\mathrm{p}<0,05)$ baik dengan kolmogrovsmirnov test maupun shapiro-wilk test. Hal ini berarti data penelitian ini tidak terdistribusi secara normal. Dengan demikian uji beda akan menggunakan Wilcoxon signed rank test.

Tabel 3. Hasil Wilcoxon Signed Rank Test

\begin{tabular}{|c|c|c|c|c|}
\hline & & $\mathbf{N}$ & Mean rank & Sum of rank \\
\hline \multirow[t]{4}{*}{ CAR (T+) - CAR (T-) } & Negative ranks & 1359 & 1435,86 & 1951335 \\
\hline & Positive ranks & 1373 & 1297,85 & 1781943 \\
\hline & Ties & 0 & & \\
\hline & Total & 2732 & & \\
\hline CAR & Z Score & $-2,055$ & Sig. & ,04 \\
\hline
\end{tabular}

Sumber: Data yang diolah (2020)

Tabel 3 menunjukan hasil uji beda dengan Wilcoxon signed rank test. Terlihat bahwa sebanyak 1.359 perusahaan mengalami penurunan nilai CAR. Rata-rata mengalami penurunan sebesar 1435,86 dengan jumlah rata-rata sebesar 195335,00. Sedangkan 1373 perusahaan lainnya mengalami peningkatan nilai CAR. Rata-rata mengalami kenaikan sebesar 1297,85 dengan jumlah rata-rata sebesar 1781943,00 . Ties adalah kesamaan nilai sebelum dan sesudah pengumuman. Nilai ties dalam tabel tersebut adalah Nol, ini berarti bahwa tidak ada nilai yang sama antara CAR sebelum dan sesudah pengumuman COVID-19.

Tabel 3 juga menunjukan hasil uji hipotesis. Tabel tersebut menunjukan Sig. (2-tailed) bernilai 0,000. Karena nilai 0,000 lebih kecil dari 0,05 maka dapat disimpulkan bahwa H1 penelitian ini diterima. Artinya terdapat perbedaan antara nilai CAR perusahaan sebelum dan setelah pengumuman COVID-19. Dengan demikian dapat disimpulkan bahwa pengumuman kasus pertama COVID-19 di Indonesia mempengaruhi CAR perusahaan publik Indonesia.

Hasil statistik menunjukan bahwa terdapat perbedaan antara nilai CAR sebelum dan sesudah pengumuman dilakukan. Penelitian ini menggunakan event pengumuman kasus COVID-19 pertama di Indonesia oleh Presiden RI pada tanggal 3 maret 2020. Umumnya karakteristik pasar modal mencerminkan prilaku investor yang sensitif. Umumnya investor berperilaku berdasarkan sifat informasi yang diterima apakah positif ataukah negatif (Wulan et al., 2018).Informasi tersebut dapat datang dari dalam pasar, seperti informasi dari perusahaan atau regulator pasar, maupun dari luar pasar, seperti informasi tentang COVID-19 yang sekarang sedang berlangsung.

Hasil statistik juga menunjukan setengah dari jumlah sampel penelitian mengalami penurunan nilai CAR dan setengah lainnya mengalami kenaikan nilai CAR. Hal ini dapat dihubungkan dengan perilaku investor dalam merespon informasi yang dianggap sebagai risiko. Pada dasarnya terdapat beberapa tipe investor dalam menanggapi risiko yaitu tipe konservatif, moderat dan agresif. Dengan demikian disimpulkan bahwa keputusan investor tergantung pada risiko yang ingin mereka hadapi. Saham yang paling terdampak COVID-19 belum tentu dihindari oleh investor, sebaliknya yang masuk kategori aman pun belum tentu diminati. 


\section{KESIMPULAN}

Event study methode memungkinkan manajer, pemilik dan investor untuk menganalisis lebih dalam tentang pengaruh dari suatu krisis seperti COVID-19. Keberadaan COVID-19 memberikan dampak pada berbagai sektor termasuk pasar modal. COVID-19 menurunkan kinerja beberapa saham perusahaan publik Indonesia. Akan tetapi tidak semua investor memandang negatif keberadaan COVID-19, sehingga beberapa perusahaan masih memiliki kinerja saham yang terbilang aman.

Penelitian ini mengkaji dampak dari pandemi COVID-19 terhadap return saham perusahaan publik Indonesia. Penelitian selanjutnya dapat membandingkan kinerja saham per sektor sehingga dapat menunjukan sektor yang paling terdampak dan yang masih terbilang aman. Hasil penelitian ini tidak hanya akan berkontribusi secara akademis tetapi juga dapat digunakan sebagai referensi bagi pelaku usaha untuk menyiapkan usahanya dalam menghadapi situasi seperti saat ini.

\section{DAFTAR PUSTAKA}

Al-Awadhi, A. M., Alsaifi, K., Al-Awadhi, A., \& Alhammadi, S. (2020). Death and contagious infectious diseases: Impact of the COVID-19 virus on stock market returns. Journal of Behavioral and Experimental Finance, 27, 100326. https://doi.org/10.1016/j.jbef.2020.100326

Chen, M. H., Jang, S. C. (Shawn), \& Kim, W. G. (2007). The impact of the SARS outbreak on Taiwanese hotel stock performance: An event-study approach. International Journal of Hospitality Management, 26(1), 200-212. https://doi.org/10.1016/j.jhm.2005.11.004

Haroon, O., \& Rizvi, S. A. R. (2020). COVID-19: Media coverage and financial markets behavior-A sectoral inquiry. Journal of Behavioral and Experimental Finance, 27, 100343. https://doi.org/10.1016/j.jbef.2020.100343

He, Q., Liu, J., Wang, S., \& Yu, J. (2020). The impact of COVID-19 on stock markets. Economic and Political Studies, O(0), 1-14. https://doi.org/10.1080/20954816.2020.1757570

Lahmiri, S., \& Bekiros, S. (2020). The impact of COVID-19 pandemic upon stability and sequential irregularity of equity and cryptocurrency markets. Chaos, Solitons and Fractals, 138, 109936. https://doi.org/10.1016/j.chaos.2020.109936

Reilly, F. K., \& Brown, K. C. (2019). Analysis of Investments and Management of Portfolios. https://www.cengage.co.in/category/higher-education/businesseconomics/finance/investment/analysis-of-investments-and-management-of-portfolios-pn

Setyawasih, R. (2007). STUDI TENTANG PERISTIWA (EVENT STUDY): Suatu Panduan Riset Manajemen Keuangan di Pasar Modal. Jurnal Fakultas Ekonomi : OPTIMAL, 1(1), 52-58.

Tahir, M. B., \& Batool, A. (2020). COVID-19: Healthy environmental impact for public safety and menaces oil market. Science of the Total Environment, 740, 140054. https://doi.org/10.1016/j.scitotenv.2020.140054

Wulan, D. C., Handayani, S. R., \& Nurlaily, F. (2018). ANALISIS ABNORMAL RETURN DAN TRADING VOLUME ACTIVITY TERHADAP PENGUMUMAN UNUSUAL MARKET ACTIVITY ( Studi pada Perusahaan yang Terdaftar dalam Pengumuman Unusual Market Activity di BEI Tahun 2015-2017 ). Jurnal Administrasi Bisnis (JAB), 61(1), 173-180.

Zhang, D., Hu, M., \& Ji, Q. (2020). Financial markets under the global pandemic of COVID-19. Finance Research Letters, 101528. https://doi.org/10.1016/j.frl.2020.101528 